\title{
PENGARUH NON PERFORMING LOAN (NPL) DAN LOAN TO DEPOSIT RATIO (LDR) TERHADAP PROFITABILITAS PADA PERUSAHAAN PERBANKAN YANG TERDAFTAR DI BURSA EFEK INDONESIA (BEI)
}

\author{
Santi Octaviani \\ antieoctavia@,gmail.com \\ Yindi Andriyani \\ Universitas Serang Raya
}

\begin{abstract}
ABSTRAK
Penelitian ini bertujuan untuk mengetahui pengaruh Non Performing Loan (NPL) dan Loan to Deposit Ratio (LDR) terhadap Profitabilitas (ROA) pada perusahaan perbankan yang terdaftar Di Bursa Efek Indonesia (BEI) .Diperoleh sampel sebanyak 4 perusahaan dengan menggunakan teknik purposive sampling. Pada penelitian ini menggunakan metode analisis linier berganda dengan menggunakan uji asumsi klasik dan uji hipotesis. Data dikumpulkan dengan studi kepustakaan mengambil dari bursa efek indonesia dan dianalisis dengan SPPS versi 21. Berdasarkan hasil penelitian dapat disimpulkan bahwa hasil analisis regresi secara parsial variabel Non Performing Loan berpengaruh signifikan terhadap Profitabilitas dan Loan to Deposit Ratio berpengaruh secara signifikan terhadap Profitabilitas. Secara simultan variabel Non Performing Loan (NPL) dan Loan to Deposit Ratio (LDR) berpengaruh signifikan terhadap Profitabilitas.
\end{abstract}

Kata Kunci:Non Performing Loan (NPL), Loan to Deposit Ratio (LDR), Profitabilitas (ROA)

\section{ABSTRACT}

This study aims to determine effect of Non Performing Loan (NPL) and Loan to Deposit Ratio (LDR) to profitability (ROA) at banking companies listed on Indonesia Stock Exchange (IDX),Obtained a sample of 4 companies using the technique is purposive sampling. In this study using multiple linear analysis using classical assumption test and test hypotheses. To take the literature study on the Indonesian stock exchange and were analyzed with SPSS version 21. Based on the results of this study concluded that the results of regression analysis partial variable Non Performing Loan significant effect on profitability and Loan to Deposit Ratio significant affect on profitability. Simultaneously Non Performing Loan (NPL) and Loan to Deposit Ratio (LDR) significant effect to profitability

Keyword : Non Performing Loan (NPL), Loan to Deposit Ratio (LDR), Profitability (ROA)

\section{PENDAHULUAN}

Perbankan merupakan lembaga keuangan yang memiliki peranan dalam sistem keuangan di Indonesia. Keberadaan sektor perbankan memiliki peranan yang cukup penting dan sangat mempengaruhi baik secara mikro maupun makro. Sistem bank juga menyebabkan sektor riil sangat rentan terhadap kinerja industri perbankan. Dalam kehidupan masyarakat modern sekarang ini, peranan perbankan dalam memajukan perekonomian suatu negara sangatlah besar. Begitu vitalnya dunia perbankan sehingga ada anggapan bahwa bank merupakan "nyawa" untuk menggerakan roda perekonomian suatu negara, seperti dalam hal penciptaan uang, menyediakan 
uang untuk kegiatan usaha, tempat mengamankan uang, tempat melakukan investasi dan jasa keuangan lainnya.(Kamsir,2009:1). Peningkatan kualitas hidup masyarakat indonesia merupakan salah satu tujuan yang hendak dicapai dalam pelaksanaan program pembangunan. Meningkatan kualitas hidup antara lain diwujudkan dengan meningkatkan pendapatan melalui berbagai kegiatan perekonomian. Salah satu sarana yang memiliki peranan strategis dalam perekonomian adalah perbankan. Keberadaan bank sangat penting bagi perekonomian suatu negara karena bank berfungsi memperlancar lalu lintas keuangan (financial intermediatery institution) yang berperan dalam mobilitas pertumbuhan ekonomi suatu negara dan merupakan bagian dari sistem moneter yang memiliki kedudukan strategis yaitu sebagai penunjang kegiatan ekonomi. Sebagai lembaga intermediasi perbankan harus memiliki kinerja yang baik, karena dengan kinerja yang baik bank akan lebih mudah mendapatkan kepercayaan dari nasabah (agent of trust). Perbankan sebagai badan usaha yang bergerak dibidang keuangan atau financial sangat membutuhkan kepercayaan dari para nasabah guna mendukung dan memperlancar kegiatan yang dilakukannya. Non performing loan merupakan rasio untuk mengukur besarnya tingkat kredit bermasalah yang terjadi pada suatu bank. Besarnya persentase NPL haruslah menjadi perhatian pihak manajemen karena kredit bermasalah yang semakin meningkat dapat membahayakan kesehatan bank tersebut. Kredit yang disalurkan oleh bank memiliki risiko terjadinya gagal bayar oleh debitur. Besarnya NPL yang diperbolehkan oleh Bank Indonesia saat ini adalah maksimal 5\%. Semakin besar tingkat NPL menunjukkan bahwa bank tersebut tidak profesional dalam pengelolaan kreditnya yang akan berdampak pada kerugian bank. Perkreditan merupakan usaha utama perbankan (financial depeding), dimana rata-rata jumlah harta bank dibanyak negara maju dan berkembang terikat dalam bentuk kredit. Tingginya angka kredit yang tersalurkan dari suatu bank dikarenakan dua alasan, yaitu dilihat dari sisi internal dan eksternal bank. Dari sisi internal, permodalan bank masih cukup kuat dan portofolio kredit meningkat, sedangkan alasan eksternal bank adalah membaiknya prospek usaha nasabah. Dengan semakin meningkatnya penyaluran kredit, salah satu permasalahan yang sering dihadapi bank dalam hal pemberian kredit adalah kredit yang diberikan berakhir menjadi kredit yang bermasalah atau kredit macet. Dalam istilah perbankan disebut dengan Non Performing Loan (NPL). Tingginya NPL di Indonesia tidak terlepas dari kurang patuhnya bank-bank di Indonesia terhadap prinsip-prinsip kehati-hatian dalam pemberian kredit.

Di Indonesia, kasus bank bermasalah karena praktik perbankan yang tidak sehat telahbanyak terjadi. Salah satunya kasus kredit macet yang menyebabkan likuidasi Bank Summa pada tahun1992 menjadi salah satu potret kelam industri perbankan di Indonesia (Suhardjanto dan Dewi,2011). Bank Summa mengalami musibah karena kreditnya yang sebagian besar disalurkan kepada grup perusahaan sendiri (Summa Grup) ternyata macet, karena proyek-proyek yang dibiayainya gagal. Summa merugi Rp.591 miliar. Dari 1,5 triliun total kredit yang disalurkannya, Rp. 1 triliun diantaranya macet. Non Performing Loan merupakan rasio yangdigunakan untuk mengukur risiko terhadap kredit yang disalurkan dengan membandingkankredit macet dengan jumlah kredit yang disalurkan (Kasmir, 2011).Bank Indonesiamenetapkan bahwa tingkat NPL yang wajar adalah $\leq 5 \%$ dari total portofolio kreditnya.Jika NPL menunjukkan adanya risiko yang berasal dari luar bank yakni dari debitur,sebaliknya Loan to Deposit Ratio dapat menggambarkan risiko yang ditanggung nasabah karena LDRmerupakan rasio yang digunakan untuk mengukur likuiditas industri perbankan. Kemampuan bank dalam memberikan pinjaman kepada masyarakat tentunya harus diimbangi dengan banyaknya simpanan yang diperoleh bank. Bank tidak dapat berjalan dan berkembang tanpa adanya penerimaan uang dalam bentuk simpanan. Namun, bank juga tidak dapat memaksimalkan labanya hanya dengan menerima simpanan dari masyarakat. 
Apabila pinjaman yang diberikan kepada masyarakat terlalu besar, maka bank akan bermasalah dengan jumlah simpanan uang yang ada di bank, bila sewaktu-waktu nasabah ingin mengambil uangnya. Sebaliknya apabila simpanan yang diperoleh dari nasabah terlalu besar, sementara bank kurang bisa menyalurkannya dalam bentuk pinjaman, maka bank tidak bisa memanfaatkan uang simpanan tersebut untuk menghasilkan laba. Oleh karena itu, diperlukan keseimbangan antara simpanan yang diterima dan pinjaman yang diberikan oleh bank. Hal ini tercermin pada Loan to Deposit Ratio (LDR) yang menggambarkan kemampuan suatu bank dalam mengendalikan simpanan dan pinjamannya. Persoalan likuiditas bagi bank adalah persoalan penting dan berkaitan erat dengan kepercayaan masyarakat, nasabah dan pemerintah. Keteledoran dalam menjaga likuiditas perlahan akan menyulitkan bank tersebut, karena secara berangsur-angsur posisi dana-dana tunai yang harus dikuasai semakin menipis. Loan to Deposit Ratio (LDR) merupakan rasio likuiditas yang membandingkan antara jumlah dana yang disalurkan kepada masyarakat (kredit) dengan jumlah dana masyarakat dan modal sendiri yang digunakan. Semakin besar penyaluran dana dalam bentuk kredit dibandingkan dengan deposit atau simpanan masyarakat pada suatu bank maka membawa konsekuensi semakin besarnya risiko yang ditanggung oleh bank yang bersangkutan.

Kunci keberhasilan sebuah bank adalah manajemen bank itu sendiri. Manajemen bank harus bisa menarik hati masyarakat supaya peranannya sebagai intermediasi keuangan berjalan baik. Salah satu indikator utama yang dijadikan dasar penilaian adalah laporan keuangan bank. Kinerja keuangan perbankan yang terlihat dari laporan keuangan menggambarkan kondisi keuangan dan hasil usaha suatu perusahaan pada jangka waktu tertentu. Berdasarkan laporan itu akan dapat dihitung sejumlah rasio keuangan yang lazim dijadikan dasar penelitian tingkat kesehatan bank. Profitabilitas sebagai salah satu acuan dalam mengukur besarnya laba untuk mengetahui apakah perusahaan telah menjalankan usahanya secara efisien. Ukuran profitabilitas yang biasa digunakan ROE untuk perusahaan pada umumnya dan return on asset (ROA) pada industri perbankan. Return on Asset (ROA) memfokuskan kemampuan perusahaan untuk memperoleh earning dalam operasi perusahaan, sedangkan Return on Equity (ROE) hanya mengukur return yang diperoleh dari investasi pemilik perusahaan dalam bisnis tersebut. Sehingga dalam penelitian ini ROA digunakan sebagai ukuran kinerja perbankan. Alasan dipilihnya Return on Asset (ROA) sebagai ukuran kinerja adalah karena ROA digunakan untuk mengukur efektifitas perusahaan didalam menghasilkan keuntungan dengan memanfaatkan aktiva yang dimilikinya. ROA merupakan rasio antara laba sebelum pajak terhadap total asset. Semakin besar ROA menunjukkan kinerja keuangan yang semakin baik, karena tingkat kembalian (return) semakin besar. Apabila ROA meningkat, berarti profitabilitas perusahaan meningkat, sehingga dampak akhirnya adalah peningkatan profitabilitas yang dinikmati oleh pemegang saham (Husnan, 1998).

Menurut Machfoedz (dalam Defri, 2012) mengatakan faktor utama yang mempengaruhi Return on Assets (ROA) bank sebagai pengukur profitabilitas bank adalah manajemen. Yaitu seluruh manajemen suatu bank, baik yang mencakup manajemen permodalan (CAR), manajemen umum (NPL), manajemen rentabilitas (NIM dan BOPO), dan manajemen likuiditas (LDR) yang pada akhirnya akan mempengaruhi dan bermuara pada perolehan laba atau return perusahaan perbankan. NPL yang tinggi akan menaikan cadangan kerugian penurunan nilai (CKPN) sehingga dapat mengurangi profitabilitas perusahaan. LDR yang terlalu tinggi akan menyebabkan rendahnya likuiditas bank tetapi LDR yang terlalu rendah memberikan indikasi kurangnya efektifitas perusahaan dalam meghasilkan laba, standar LDR berdasarkan peraturan BI No. 15/7/PBI/2013 yaitu 78\%-92\%. 


\section{Landasan Teori}

\section{Non Performing Loan (NPL)}

Menurut Ismail (2009:226), NPL (Non Performing Loan) adalah kredit yang menunggak melebihi 90 hari. Dimana NPL terbagi menjadi kredit kurang lancar, diragukan, dan macet. Semakin kecil NPL maka semakin kecil pula risiko kredit yang ditanggung oleh pihak bank. Bank dalam melakukan kredit harus melakukan analisis terhadap kemampuan debitur untuk membayar kembali kewajibannya. Setelah kredit diberikan, bank wajib melakukan pemantauan terhadap penggunaan kredit serta

Rumus NPL yaitu (SE BI 13/30/DPNP 16 Desember 2011):

$$
\mathrm{NPL}=\frac{\text { Kredit Bermasalah }}{\text { Total Kredit }} \times 100 \%
$$

\section{Loan to Deposit Ratio}

Menurut Pauzi (2010) LDR menyatakan kemampuan suatu bank untuk membayar kembali dana milik nasabah yang tertanam dalam bank tersebut dengan mengandalkan kredit yang disalurkan sebagai sumber likuiditasnya. Loan to deposit ratio (LDR) menyatakan seberapa jauh kemampuan bank membayar kembali penarikan yang dilakukan nasabah deposan dengan mengandalkan kredit yang diberikan sebagai sumber likuiditasnya (Sianturi, 2012). LDR diukur dengan skala rasio dan besarnya dinyatakan dalam persen (\%). Rumus LDR yaitu (SE BI 13/30/DPNP 16 Desember 2011):

$\frac{\text { Jumlah Kredit Yang Diberikan }}{\text { Total Dana Pihak Ketiga }} \times 100 \%$

\section{Profitabilitas}

Menurut pendapat Kasmir (2012:196), mengatakan bahwa rasio profitabilitas adalah rasio untuk menilai kemampuan perusahaan dalam mencari keuntungan. Rasio ini juga memberikan ukuran tingkat efektivitas manajemen suatu perusahaan. Adapun menurut Sofyan Safri Harahap (2011:304), mendefinisikan rasio profitabilitas adalah rasio yang menggambarkan kemampuan perusahaan mendapatkan laba melalui semua kemampuan, dan sumber yang ada seperti kegiatan penjualan, kas, modal, jumlah karyawan, jumlah cabang, dan sebagainya. Menurut Irham Fahmi (2011:137), Rasio return on investment (ROI) Rumus dari return on investment (ROI) adalah :

$$
\text { ROI }=\frac{\text { Laba setelah pajak }}{\text { Total Aset }} \times 100 \%
$$

\section{Hipotesis Penelitian}

\section{Pengaruh Non performing Loan terhadap Profitabilitas}

NPL merupakan rasio yang digunakan untuk mengukur risiko terhadap kredit yang disalurkan dengan membandingkankredit macet dengan jumlah kredit yang disalurkan (Kasmir, 2011).Bank Indonesiamenetapkan bahwa tingkat NPL yang wajar adalah $\leq 5 \%$ dari total portofolio kreditnya. Tingginya NPL akan diiringi dengan meningkatanya cadangan kerugian penurunan nilai (CKPN). CKPN yang tinggi akan mengurangi kontribusi margin perusahaan sehingga dapat 
mengurangi profitabilitas perusahaan. Maka Hipotesis : Non Performing Loan berpengaruh signifikan terhadap profitabilitas.

\section{Pengaruh Loan to Deposit Ratio Terhadap Profitabilitas}

LDR menyatakan seberapa jauh kemampuan bank membayar kembali penarikan yang dilakukan nasabah deposan dengan mengandalkan kredit yang diberikan sebagai sumber likuiditasnya (Sianturi, 2012). Berdasarkan PBI No. 15/7/PBI/2013 standar LDR yaitu 78\% - 92\%. Jika rasio LDR bank mencapai lebih dari 92\% maka total kredit yang disalurkan oleh bank tersebut telah melebihi dana yang dihimpun. Bank dituntut untuk mampu menjaga likuiditasnya agar tetap mendapatkan kepercayaan dari masyarakat. Besar kecilnya LDR suatu bank akan mempengaruhi profitabilitas bank tersebut. Maka Hipotesis: Loan to Deposit Ratio berpengaruh signifikan terhadap profitabilitas.

\section{Pengaruh Non Performing Loan dan Loan to Deposit Ratio terhadap Profitabilitas}

Menurut Irham Fahmi (2011:135), mengatakan bahwa rasio profitabilitas adalah rasio yang mengukur efektivitas secara keseluruhan yang ditunjukan oleh besar kecilnya tingkat keuntungan yang diperoleh dalam hubungannya dengan penjualan maupun investasi. Jika rasio NPL rendah dan LDR tidak melebihi standar yang ditetapkan BI maka rasio profitabilitasnya akan tinggi .Maka Hipotesis : Non Performing Loan dan Loan to Deposit Ratio berpengaruh signifikan terhadap profitabilitas.

\section{Metode Penelitian}

Dalam penelitian ini metode yang digunakan adalah metode penelitian kuantitatif karena data penelitian berupa angka-angka dan analisisnya menggunakan statistik. Untuk melakukan sebuah penelitian diperlukan desain penelitian untuk membuat rangkaian rencana, gambaran dan penjelasan yang tersusun sehingga mendapatkan kemudahan dalam pelaksanaan penelitian. Desain penelitian yang digunakan yaitu desain kausal, desain kausal ini mengkaji secara mendalam dan menyeluruh sebab akibat sekaligus untuk mencari tahu bagaimana keterkaitan antara variabel dan masalahnya pada tujuan penelitian yaitu untuk mengetahui Pengaruh NPL dan LDR terhadap Profitabilitas. Populasi dalam penelitian ini adalah seluruh perusahaan perbankan yang terdaftar di Bursa Efek Indonesia periode 2008-2015 sebanyak 43 perusahaan perbankan. Pengambilan sampel dalam penelitian ini dilakukan dengan metode"purposive sampling".

\section{Oprasional Variabel}

Tabel Operasional Variable

\begin{tabular}{llll}
\hline Variabel & Definisi & Indikator & Skala \\
\hline Non Performing & presentase jumlah kredit & 1. Kredit bermasalah & Ratio \\
Loan (X1) variabel & bermasalah (Kriteria kurang & 2. Total Kredit & \\
independen & lancar, diragukan, macet) & & \\
& terhadap total kredit yang & & \\
& disalurkan & &
\end{tabular}




\begin{tabular}{|c|c|c|}
\hline Loan to Deposit & rasio yang digunakan untuk & 1. Total kredit \\
\hline Ratio (X2) & mengukur komposisi jumlah & 2. DPK \\
\hline merupakan variabel & kredit yang diberikan & \\
\hline independen & $\begin{array}{l}\text { dibandingkan dengan jumlah } \\
\text { dana masyarakat dan modal } \\
\text { sendiri yang digunakan }\end{array}$ & \\
\hline $\begin{array}{l}\text { Profitabilitas }(Y) \\
\text { variabel dependent }\end{array}$ & $\begin{array}{l}\text { profitabilitas diukur dengan } \\
\text { menggunakan ROA. Rasio ini } \\
\text { adalah rasio keuntungan bersih } \\
\text { setelah pajak terhadap jumlah } \\
\text { asset secara keseluruhan }\end{array}$ & $\begin{array}{l}\text { 1. Laba sebelum } \\
\text { pajak } \\
\text { 2. Total aset }\end{array}$ \\
\hline
\end{tabular}

\section{Statistik Deskriptif}

Statistik deskriptif adalah statistik yang digunakan untuk menganalisa data dengan cara mendeskripsikan atau menggambarkan data yang telah terkumpul sebagaimana adanya tanpa bermaksud membuat kesimpulan yang berlaku untuk umum atau generalisasi (Sugiyono, 2014:206). Dalam penelitian ini statistik deskriptif yang dilakukan dengan cara menghitung mean, minimum, maximum serta standar deviasi yang bertujuan mengetahui distribusi data yang menjadi sampel penelitian.

\section{Hasil penelitian dan Pembahasan Uji Normalitas}

\section{Hasil Uji Normalitas}

\begin{tabular}{llr}
\multicolumn{2}{c}{ One-Sample Kolmogorov-Smirnov Test } \\
\hline $\mathrm{N}$ & & $\begin{array}{c}\text { Unstandardized } \\
\text { Residual }\end{array}$ \\
\hline Normal Parameters ${ }^{\mathrm{a}, \mathrm{b}}$ & Mean & 32 \\
& Std. Deviation & .0000000 \\
Most Extreme Differences & Absolute & .64849274 \\
Kolmogorov-Smirnov Z & Positive & .177 \\
Asymp. Sig. (2-tailed) & Negative & .177 \\
a. Test distribution is Normal. & & .112 \\
b. Calculated from data. & & .999 \\
\end{tabular}

Berdasarkan tabel di atas, dapat diketahui bahwa jumlah sampel yang dimasukan dalam pengujian ini adalah 32 data. Nilai Kolmogorov-Smirnov $Z$ sebesar 0,999 dan nilai signifikannya (Asymp. Sig. (2-tailed) sebesar 0,271 >0,05 yang berarti data residual berdistribusi normal.

\section{Uji Regresi Linier Berganda}

\section{Hasil Regresi Linier Berganda}


Coefficients $^{a}$

\begin{tabular}{lllllll}
\hline Model & & $\begin{array}{c}\text { Unstandardized } \\
\text { Coefficients } \\
\text { Std. Error }\end{array}$ & $\begin{array}{c}\text { Standardized } \\
\text { Coefficients } \\
\text { Beta }\end{array}$ & $\mathrm{t}$ & Sig. \\
\hline $1 \quad$ B & 8.074 & .785 & & 10.282 & .000 \\
& $\begin{array}{l}\text { (Constant) } \\
\text { Non Performing }\end{array}$ & -.882 & .120 & -.751 & -7.333 & .000 \\
& $\begin{array}{l}\text { Loan } \\
\text { Loan to Deposit } \\
\text { Ratio }\end{array}$ & -.029 & .008 & -.365 & -3.565 & .001 \\
\hline
\end{tabular}

a. Dependent Variable: Return on Assets

Dari perhitungan regresi diatas maka dapat dibentuk persamaan sebagai berikut: $\mathrm{Y}=8,074$ - 0,882. NPL - 0,029. LDR + e

\section{Hasil Pengujian Hipotesis dan Pembahasan Uji Koefisensi Determinasi $\left(R^{2}\right)$}

\section{Hasil Uji Koefisisen Determinasi}

\begin{tabular}{lcccc}
\multicolumn{4}{c}{ Model Summary } \\
\hline Model & $\mathrm{R}$ & R Square & $\begin{array}{c}\text { Adjusted R } \\
\text { Square }\end{array}$ & $\begin{array}{c}\text { Std. Error of the } \\
\text { Estimate }\end{array}$ \\
\hline 1 & $.834^{\mathrm{a}}$ & .696 & .675 & .67048 \\
\hline a. Predictors: (Constant), Loan to Deposit Ratio, Non Performing Loan \\
b. Dependent Variable: Return on Assets
\end{tabular}

Dari table Model Summary terlihat nilai $R$ Square $\left(\mathrm{R}^{2}\right)$ atau koefisien Determinasi sebesar 0,696 atau 69,6\% sedangkan sisanya 30,4\% dijelaskan oleh variable lain diluar model.

\begin{tabular}{|c|c|c|c|c|c|c|}
\hline & & & $\begin{array}{l}\text { Hasil Uj } \\
\text { efficients }^{\text {a }}\end{array}$ & Hipotesis & & \\
\hline Model & & $\begin{array}{r}\text { Unstan } \\
\text { Coef }\end{array}$ & $\begin{array}{l}\text { lardized } \\
\text { cients }\end{array}$ & $\begin{array}{l}\text { Standardized } \\
\text { Coefficients }\end{array}$ & $t$ & Sig. \\
\hline & & $B$ & Std. Error & Beta & & \\
\hline & (Constant) & 8.074 & .785 & & 10.282 & .000 \\
\hline 1 & $\begin{array}{l}\text { Non Performing } \\
\text { Loan }\end{array}$ & -.882 & .120 & -.751 & -7.333 & .000 \\
\hline & $\begin{array}{l}\text { Loan to Deposit } \\
\text { Ratio }\end{array}$ & -.029 & .008 & -.365 & -3.565 & .001 \\
\hline
\end{tabular}

a. Dependent Variable: Return on Assets

Pada Bagian ini akan dipaparkan pembahasan mengenai hasil analisis yang telah dilakukan. Hasil analisis tersebut dijelaskan sebagai berikut:

Pengaruh Non Performing Loan (NPL) terhadap profitabilitas (ROA)

Berdasarkan hasil uji parsial, Non Performing Loan (NPL) berpengaruh signifikan terhadap profitabilitas (ROA) pada perusahaan perbankan yang terdaftar di BEI Tahun 20082015. Hasil penelitian ini konsisten dengan hasil penelitian Delsy Setiawati Ratu Edo dan Ni Luh Putu Wiagustini (2014). Hasil penelitian menyatakan bahwa NPL berpengaruh negatif dan 
signifikan terhadap ROA. Dari hasil penelitian diperoleh nilai signifikansi 0,02 dan koefisien regresinya -0,224. Sedangakan Hasil penelitian ini tidak sesuai dengan penelitian yang dilakukan Febrianti Dian Suminar, Nurul Qomari dan Juliani Pudjowati (2014). Dalam penelitiannya menyatakan bahwa NPL secara parsial tidak berpengaruh terhadap ROA dengan koefisien regresinya $-3,615$.

\section{Pengaruh Loan to Deposit Ratio (LDR) terhadap profitabilitas (ROA)}

Berdasarkan hasil uji parsial, Loan to Deposit Ratio (LDR) berpengaruh signifikan terhadap profitabilitas (ROA) pada perusahaan perbankan yang terdaftar di BEI Tahun 20082015. Hasil penelitian ini konsisten dengan hasil penelitian Ni Kadek Yuni Widiasari dan Ni Putu Sri Harta Mimba (2015). LDR berpengaruh positif terhadap profitabilitas dengan nilai signifikansi sebesar 0,008. Hasil penelitian ini tidak sesuai dengan penelitian yang dilakukan Febrianti Dian Suminar, Nurul Qomari dan Juliani Pudjowati (2014). Dalam penelitiannya menyatakan bahwa LDR secara parsial tidak berpengaruh terhadap ROA dengan koefisien regresinya $-2,090$.

\section{Pengaruh Non Performing Loan (NPL) dan Loan to Deposit Ratio (LDR) terhadap profitabilitas (ROA)}

Berdasarkan hasil pengujian secara bersamaan atau simultan, diketahui bahwa kedua variabel independen, yaitu Non Performing Loan (NPL) dan Loan to Deposit Ratio (LDR) berpengaruh signifikan terhadap profitabilitas (ROA). Nilai koefisien determinasi sebesar 69,6\% yang berarti bahwa variabel Non Performing Loan dan Loan to Deposit Rasio mempengaruhi sebesar 69,6\% terhadap Profitabilitas (ROA). Dengan demikian variabel Non Performing Loan dan Loan to Deposit Rasio dapat dijadikan pertimbangan dalam mengukur profitabilitas pada perusahaan perbankan yang terdaftar di BEI Tahun 2008-2015.

\section{Penutup}

Penelitian ini meneliti apakah Non Performing Loan (NPL), Loan to Deposit Ratio (LDR) dapat mempengaruhi profitabilitas profitabilitas pada perusahaan perbankan yang terdaftar di Bursa Efek Indonesia (BEI) tahun 2008-2015. Hasil pengujian hipotesis dengan menggunakan alat uji $\mathrm{t}$ dan $\mathrm{f}$. Berdasarkan hasil penelitian tersebut, maka dapat ditarik kesimpulan sebagai berikut: 1). Berdasarkan uji t yang telah dilakukan secara parsial membuktikan bahwa Non Performing Loan (NPL) memiliki pengaruhyang signifikan terhadap profitabilitas pada perusahaan perbankan yang terdaftar di Bursa Efek Indonesia (BEI) tahun 2008-2015. 2). Berdasarkan uji t yang telah dilakukan secara parsial membuktikan bahwa Loan to Deposit Ratio (LDR) memiliki pengaruh yang signifikan terhadap profitabilitas pada perusahaan perbankan yang terdaftar di Bursa Efek Indonesia (BEI) tahun 2008-2015. 3). Berdasarkan uji f yang telah dilakukan secara bersama - sama (simultan) membuktikan bahwa Non Performing Loan (NPL) dan Loan to Deposit Ratio (LDR) memiliki pengaruh yang signifikan terhadap profitabilitas pada perusahaan perbankan yang terdaftar di Bursa Efek Indonesia (BEI) tahun 2008-2015.

\section{DAFTAR PUSTAKA}

Fahmi Irham. (2014). Pengantar Perbankan Teori \& Aplikasi. Bandung : Alfabeta. 
Husein, Umar. (2007). Metode Penelitian Untuk Skripsi Dan Tesis Bisnis. Jakarta : PT. Raja Grafindo Persada.

Kasmir. (2015). Analisis Laporan Keuangan. Jakarta : PT Raja Grafindo Persada.

Sugiono, (2014). Metode Penelitian Kuantitatif Kualitatif dan R\&D. Bandung : Alfabeta.

Undang-Undang No. 10 tahun 1998 (Perubahan Undang-Undang No 7 tahun 1992 tentang Perbankan)

Adam, Ulfawaty. (2013). pengaruh non performing loan (NPL) dan biaya operasiona pendapatan operasional (BOPO) terhadap profitabilitas bank (ROA) penelitian pada PT Bank Negara Indonesia, tbk periode 2000-2011). Gorontalo : Jurnal Fakultas Ekonomi dan Bisnis.

Choerudin, Achmad. Eny dan Bambang. (2016). Pengaruh Non Perfoming Loajn (Npl) Dan Loan To Deposit Ratio (Ldr) Terhadap Return On Asset (Roa) Dengan Capital Adequacy Ratio (Car) Sebagai Variabel Intervening (Studi Pada Bank Umum Yang Terdaftar Di Bei Periode Tahun 2012-2015). Surakarta : Jurnal Ekonomi dan Perbankan

Dian Suminar, Febriyanti. (2014). Analisis pengaruh Capital Adequacy Ratio (CAR), Non Performing Loan (NPL) dan Loan to Deposit Ratio (LDR) pada Bank BUMN yang terdaftar di BEI Periode 2009-2018. Surabaya : Jurnal Manajemen Branchmarck.

Pasaribu, Hiras. dan Rosa. (2011). Analisis tingkat kecukupan modal dan loan to deposit ratio terhadap profitabilitas. Yogyakarta : Jurnal telaah Vol. 4. No.2

Rustamto Putra, Rizal. (2015). Analisis pengaruh non performing loan (npl) dan loan to deposit ratio (ldr) terhadap profitabilitas pada pt. bank syariah mandiri periode $(2010-2014)$. Surakarta : PUBLIKASI ILMIAH Universitas Muhammadiyah Surakarta.

Septiani, Rita dan Putu. (2016). Pengaruh NPL Dan LDR Terhadap Profitabilitas dengan car sebagai variabel mediasi pada PT BPR Pasar Raya Kuta. Bali : E-Jurnal Manajemen Unud, Vol. 5, No.1

Setiawati, Delsy. Dan Ni Luh. (2014). Pengaruh Dana Pihak Ketiga, Non Performing Loan, Dan Capital Adequacy Ratio Terhadap Loan To Deposit Ratio Dan Return On Assets Pada Sektor Perbankan Di Bursa Efek Indonesia. Bali : E-Jurnal Ekonomi dan Bisnis Universitas Udayana.

Yuni, Widiasari. dan Sri. (2015). Pengaruh Loan To Deposit Ratio Pada Profitabilitas Dengan Non Performing Loan Sebagai Pemoderasi. Bali : E-Jurnal Akuntansi Universitas Udayana 
Jurnal Akuntansi, Vol 5 No. 1 Januari 2018

p-ISSN 2339-2436

e-ISSN 2549-5968

www.sahamok.com 